\title{
ANALISIS AKTIVITAS BELAJAR MAHASISWA NON-PENDIDIKAN DASAR UPBJJ-UT PADANG
}

\author{
Andriyansah dan Fatia Fatimah \\ FE dan FMIPA UPBJJ Universitas Terbuka Padang \\ email: andriyansah@ut.ac.id
}

\begin{abstract}
Abstrak: Penggiatan usaha dari Unit Program Belajar Jarak Jauh perlu dilakukan untuk meningkatkan jumlah mahasiswa Non-Pendidikan Dasar. UPBJJ-UT Padang memiliki jumlah aktif mahasiswa NonPendas yang sama setiap masa registrasi, persentase kelulusan mahasiswa kurang dari $8 \%$. Salah satu perbaikan untuk peningkatan persentase lulusan melalui optimalisasi aktivitas belajar dari mahasiswa. Aktivitas belajar dapat meningkatkan hasil belajar. Penelitian ini bertujuan untuk menjelaskan aktivitas belajar, faktor, dan dampaknya terhadap prestasi belajar pada mahasiswa. Metode penelitian yang digunakan adalah deskriptif kuantitatif. Populasi penelitian ini adalah mahasiswa Non-Pendas UPBJJUT Padang masa registrasi 2012.1 sebanyak 920 orang. Aktivitas belajar mahasiswa masih rendah karena motivasinya hanya mengejar ijazah. Faktor yang berperan adalah ikut tutorial online, akses layanan belajar, dan membeli buku di toko buku online. Layanan belajar dan bahan ajar berpengaruh signifikan terhadap prestasi belajar.
\end{abstract}

Kata Kunci : analisis, aktivitas belajar, prestasi belajar

\section{AN ANALYSIS OF THE NON-ELEMENTARY-EDUCATION STUDENTS OF UPBJJ-UT PADA}

\begin{abstract}
To activate effort of the Distance Learning Program Unit is needed to increase the number of the non-elementary-education students. The number of the non-elementary-education students is the same each registration period. However, the percentage of the graduates is less than $8 \%$. One improvement to increase the percentage of the graduates through the optimum student learning activities. Learning activities could improve learning achievement. This study aimed to describe the learning activities, the factors and their impact on students' achievement. The research method used the descriptive quantitative method. The population was non-elementary-education students of UPBJJ-UT Padang in the 2012.1 registration period consisting of 920 students. Their learning activities were low because their intention was only for getting the certificate. Factors that affected the learning activities were to participate in online tutorials, to access learning services and to buy books at online bookstores. The learning service and teaching materials significantly influenced the learning achievement.
\end{abstract}

\section{Keywords: analysis, learning activities, learning achievement}

\section{PENDAHULUAN}

Tujuan didirikan Universitas Terbuka(UT) adalah untuk memberikan layanan pendidikan tinggi bagi pekerja atau karena alasan lain sehingga tidak dapat melanjutkan pendidikan di perguruan tinggi tatap muka. UT menawarkan berbagai program pendidikan yang bermutu pada jenjang pendidikan tinggi dengan menggunakan Sistem Pendidikan Jarak Jauh (SPJJ) yang dapat diakses oleh seluruh lapisan masyarakat, menghasilkan bahan ajar tingkat pendidikan tinggi yang bermutu dalam bentuk beragam media, serta menawarkan berbagai ben- tuk layanan bantuan belajar untuk meningkatkan kualitas pembelajaran dan lulusan.

UT menyelenggarakan dua program pendidikan yang diberi istilah Program Pendidikan Dasar (Pendas) dan Program Non-Pendas. Program Pendas merupakan program yang diselenggarakan secara khusus bagi guru Sekolah Dasar dan guru Pendidikan Anak Usia Dini. Program Non-Pendas adalah program yang dapat diikuti oleh masyarakat umum kecuali program Non-Pendas Fakultas Keguruan dan Ilmu Pendidikan yang diselenggarakan bagi guru (Tim UT, 2012). Program Pendas dibantu 
oleh pemerintah dengan peraturan yang mengharuskan guru pendidikan dasar berkualifikasi minimal Strata Satu (S1). Akibatnya, rekrutmen mahasiswa baru Pendas punya pangsa pasar tersendiri. Di sisi lain, mahasiswa baru NonPendas tidak didukung oleh program terkait.

Penggiatan usaha dari Unit Program Belajar Jarak Jauh (UPBJJ) Padang perlu dilakukan untuk meningkatkan jumlah mahasiswa Non-Pendas. Peningkatan jumlah mahasiswa tersebut melalui sosialisasi promosi baik nasional maupun lokal serta memberikan pelayanan prima. Pelayanan yang diberikan diharapkan dapat membantu mahasiswa dalam menyelesaikan studinya dengan cepat dan memiliki indeks prestasi yang memuaskan.

UPBJJ-UT Padang memiliki jumlah aktif mahasiswa Non-Pendas secara rata-rata sama setiap masa registrasi. Registrasi 2010.1 sebanyak 1.031 mahasiswa yang aktif, 1.039 mahasiswa pada 2010.2, 1.059 mahasiswa di 2011.1, dan 1.047 mahasiswa pada registrasi 2011.2. Jumlah mahasiswa yang lulus dari 2010.1 sampai 2011.2 secara berurutan adalah 80, 9, 34, dan 7 mahasiswa. Hal itu berarti persentase kelulusan mahasiswa kurang dari $8 \%$.

Salah satu perbaikan untuk peningkatan persentase lulusan melalui optimalisasi aktivitas belajar yang dilakukan oleh mahasiswa. Hal ini karena, aktivitas belajar dapat meningkatkan hasil belajar (Idiarman, 2009; Erita, 2009). Indikator aktivitas belajar dapat dilihat dari aktivitas visual, berbicara, mendengarkan, menulis, motorik, mental serta aktivitas secara emosional (Sardiman, 2006). Aktivitas belajar mahasiswa UT didasari oleh filosofi belajar mandiri. Belajar mandiri dibantu oleh media dan fasilitas yang diberikan oleh UT yaitu layanan belajar dan bahan ajar. Hal ini perlu keinginan yang kuat dan aktivitas belajar yang konsisten dari mahasiswa. Oleh karena itu, perlu dilakukan penelitian tentang analisis aktivitas belajar mahasiswa Non-Pendas.

Hal ini diperlukan sebagai landasan pengambilan kebijakan dan dasar memotivasi mahasiswa agar dapat menyelesaikan pendidikannya di UT tepat waktu. Penelitian bertujuan untuk menjelaskan aktivitas belajar dan faktor- faktor yang mempengaruhinya serta dampaknya terhadap prestasi belajar pada mahasiswa NonPendas di UPBJJ-UT Padang. Hasil penelitian ini diharapkan dapat memberikan penjelasan tentang faktor yang mempengaruhi keberhasilan mahasiswa dalam belajar di perguruan tinggi jarak jauh, menjadi bahan kebijakan dan bahan evaluasi dalam mengambil keputusan berkenaan peningkatan kualitas output mahasiswa di perguruan tinggi jarak jauh, khususnya UPBJJUT Padang.

\section{METODE}

Metode penelitian yang digunakan adalah deskriptif kuantitatif. Populasi dalam penelitian ini adalah mahasiswa Non-Pendas UPBJJ-UT Padang masa registrasi 2012.1 sebanyak 920 orang. Teknik pengambilan sampel adalah random sampling. Instrumen yang digunakan dalam penelitian ini adalah wawancara dan kuesioner (pilihan ganda dan uraian). Data aktivitas belajar mahasiswa Non-Pendas di UPBJJ-UT Padang dilakukan secara wawancara dibeberapa lokasi yaitu: kabupaten Pesisir Selatan: Lunang Silaut dan Tapan, kota Sawahlunto, kabupaten Pasaman Timur: Rao, kabupaten 50 Kota: Bukit Barisan, Mungka dan Harau, serta kota Payakumbuh. Teknik pengumpulan data menggunakan dua jenis data, yaitu data primer dan data sekunder.

Analisis data untuk menjawab permasalahan faktor-faktor yang mempengaruhi aktivitas belajar mahasiswa Non-Pendas di UPBJJUT Padang menggunakan analisis regresi linear berganda (Sugiyono,2007). Berikut rumus yang digunakan.

$$
\begin{array}{ll}
\hat{Y}=a_{0}+a_{1} X_{1}+ & a_{2} X_{2}+\ldots .+a_{n} X_{n} \\
\hat{Y} & : \text { Aktivitas belajar } \\
X_{1}, X_{2}, . ., X_{n} & : \text { Faktor-faktor yang } \\
& \text { mempengaruhi aktivitas } \\
a_{0}, a_{1}, \ldots, a_{n} \quad: \text { koefisien }
\end{array}
$$

Analisis masing-masing aktivitas belajar dengan prestasi belajar mahasiswa Non-Pendas di UPBJJ-UT Padang menggunakan Analisis korelasi Product Moment Pearson (Sugiyono, 2007). Kerangka berpikir penelitian ini dapat dilihat pada Gambar 1. 


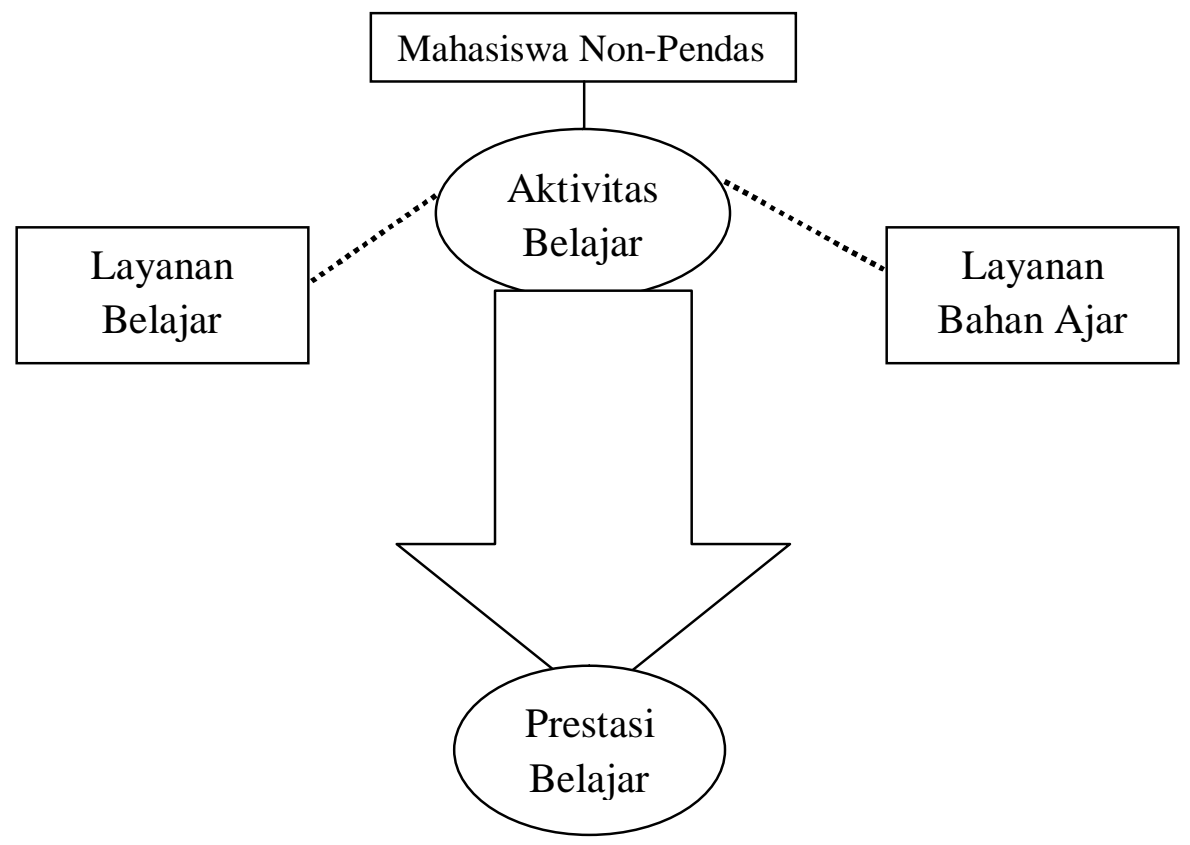

Gambar 1. Kerangka Berpikir

Instrumen yang digunakan dalam penelitian ini adalah wawancara dan kuesioner. Instrumen sebagai pedoman wawancara dan butir kuesioner sesuai dengan kisi-kisi yang telah dibuat. Teknik pengumpulan data menggunakan dua jenis data yang dikelompokkan ke dalam (1) data primer (data tentang faktorfaktor yang mempengaruhi aktivitas belajar. Data tersebut diperoleh dari hasil wawancara dan kuesioner terhadap mahasiswa Non-Pendas yang menjadi sampel penelitian); (2) data sekunder (data yang diperoleh dari hasil belajar mahasiswa Non-Pendas. Data ini diperlukan untuk melihat gambaran umum tentang prestasi belajar mahasiswa Non-Pendas pada masa ujian 2011.2 di UPBJJ-UT Padang).

Sebelum data dianalisis dilakukan pemeriksaan data kuesioner. Pemeriksaan dilakukan untuk mengetahui apakah data yang terkumpul cukup baik dan layak untuk dianalis lebih lanjut. Pemeriksaan berikutnya dilakukan dengan cara meneliti hasil penyebaran kuesioner dengan memperhatikan kelengkapan pengisian jawaban, kejelasan tulisan, dan kejelasan makna jawaban. Teknik analisis data yang digunakan adalah analisis deskriptif. Analisis data kuesioner dibagi atas dua model butir pertanyaan yaitu pilihan ganda dan uraian. Hasil data per butir kuesioner disajikan dalam bentuk tabel, perhitungan rata-rata, serta persentase. Analisis deskriptif data penelitian serta penyajiannya dilakukan dengan bantuan program SPSS 14.

Untuk memudahkan dalam mamahami isi penelitian ini, didefinisikan beberapa variabel, sebagai berikut. (1) Aktivitas Belajar: tindakan atau cara seseorang dalam memahami pelajaran dengan mengacu kepada pola dan sistem pembelajaran pada suatu institusi pendidikan dalam hal ini mahasiswa Universitas Terbuka untuk belajar. (2) Layanan Belajar: sistem Pendidikan jarak jauh tidak mengenal kuliah tatap muka sehingga untuk membantu mahasiswa memahami materi kuliah Institusi pendidikan menyediakan pola layanan belajar, berupa tutorial tatap muka atas permintaan mahasiswa, tutorial online. (3) Bahan Ajar: referensi untuk memahami matakuliah tidak terbatas pada bahan media cetak, eleltronik maupun non cetak, dengan demikian dari sumber manapun jenisnya bisa digali.

\section{HASIL DAN PEMBAHASAN}

Penelitian ini menggunakan responden mahasiswa yang meregistrasi pada tahun akademik 2012 dengan jumlah kuesioner yang disebar sebanyak 200 lembar kuesioner. Dari 
kuesioner tersebut yang kembali dan dapat diolah sebanyak 150 lembar kuesioner.

\section{Aktivitas Belajar}

Dari lima kabupaten yang menjadi objek penelitian, didapat 15 orang responden yang bersedia diwawancara dan memberikan jawaban.

- Apa alasan saudara memilih kuliah di UT? (100\% jawaban dari responden menjawab tidak mengganggu jam kerja sehingga tidak harus meninggalkan tugas rutin sebagai pegawai).

- Bagaimana pola belajar tutorial tatap muka? (Responden menjawab tidak mengikuti tutorial tatap muka. Pada dasarnya responden mengetahui kalau ada fasilitas untuk tutorial tatap muka. Akan tetapi sulit untuk mengetahui teman sejawat yang mengambil mata kuliah yang sama pada semester berjalan).

- Apakah anda menggunakan tutorial online? (Lima orang responden atau 33,3\% menjawab menggunakan tutorial sebagai sumber belajar sejak menjadi mahasiswa UT, sedangkan 64\% responden menjawab tidak ikut tutorial online dengan beragam argumen antara lain sulit $\log$ in, jaringan internet susah serta kurang yakin kalau nilai tutor mempengaruhi nilai).

- Apakah anda memiliki bahan ajar cetak dari UT? (Responden yang menjawab memiliki Buku Materi Pokok (BMP) sebanyak 53\% dengan metode kepemilikan yang berbeda. Ada yang membeli di Toko Buku Online (TBO) dan ada yang membeli dari teman kakak kelas yang bertemu pada saat ujian akhir semester. Sementara $47 \%$ menjawab tidak memiliki dan tidak pernah mengakses TBO karena berharap BMP dapat diakses di toko buku pada umumnya).

- Apakah anda memakai sumber belajar lain? (Sebanyak 100\% responden mengaku memiliki sumber belajar lain, namun jarang dimanfaatkan karena tidak dapat membantu mengisi ujian akhir selain BMP dari UT, jadi kalau tidak ada BMP responden menjawab menebak saja ketika menjawab ujian dan tiak ada memperkaya informasi materi kuliah).

- Kapan waktu efektif anda dalam belajar? (Responden menjawab memilih UT karena sulitnya untuk membagi waktu belajar dengan membagi waktu untuk melaksanankan tugas sebagai pegawai).

- Apakah anda suka belajar sendiri atau berkelompok? (Responden menjawab sendiri dan kelompok mempunyai kekurangan dan kelebihan masing-masing, namun sebanyak $80 \%$ menjawab menginginkan belajar berkelompok dan $20 \%$ menjawab lebih memilih belajar sendiri karena sulit membagi waktu dan mengatur keuangan).

- Apakah strategi yang anda pakai selama ini dalam menguasai kompetensi yang disyaratkan untuk setiap matakuliah? (100\% responden menjawab tidak karena pada prinsipnya bukan mencari ilmu tetapi mencari ijazah tanpa menggangu waktu sebagai pegawai).

Aktivitas merupakan bagian yang terpenting dari proses belajar karena aktivitas adalah suatu kegiatan siswa selama proses pembelajaran berlangsung. Tanpa kegiatan tidak mungkin seorang siswa dikatakan belajar. Zaini (2002) mengatakan orang dewasa itu biasanya mampu mengarahkan dirinya sendiri, memunyai pengalaman yang beragam, dan siap belajar akibat kebutuhan dirinya.

\section{Faktor-faktor yang Berperan}

Faktor yang dapat mempengaruhi aktivitas belajar mahasiswa Non-Pendas di UPBJJ-UT Padang dilihat dari 2 faktor yaitu faktor internal dan eksternal. Faktor internal berupa usia, jenis kelamin, status pekerjaan, latar belakang pendidikan, tujuan kuliah di UT, dan motivasi kuliah di UT.

\section{Usia}

Penelitian ini menklusterkan usia responden ke dalam 4 kelompok, dari responden yang mengisi kuesioner didapat data mengenai usia. Untuk yang mengisi kurang dari 25 tahun adalah sebanyak 59 orang, usia 26-35 tahun tidak ada yang mengisi, usia 45 tahun ke bawah yang mengisi sebanyak 67 orang responden 
sedangkan yang mengisi kuesioner untuk usia 45 tahun keatas sebanyak 24 orang. Tingkat persentase dapat dilihat pada Tabel 1 .

Tabel 1. Usia Mahasiswa Mahasiswa NonPendas UPBJJ-UT Padang

\begin{tabular}{clc}
\hline No. & Kategori & Persentase \\
\hline 1. & Kurang Dari 25 & 19 \\
2. & Tahun & - \\
26-35 Tahun & 45 Tahun Kebawah & 22.3 \\
4. & 45 Tahun Keatas & 8.0 \\
\hline
\end{tabular}

\section{Jenis Kelamin}

Pada penelitian ini faktor internal mengenai jenis kelamin, dari 150 kuesioner yang kembali didapat data 94 kuesioner berjenis kelamin laki-laki dan 56 orang perempuan. Tingkat persentase dapat dilihat pada Tabel 2.

Tabel 2. Jenis Kelamin Mahasiswa NonPendas UPBJJ-UT Padang

\begin{tabular}{clc}
\hline No. & Kategori & Persentase \\
\hline 1. & Laki-laki & 31.3 \\
2. & Perempuan & 18.7 \\
\hline
\end{tabular}

\section{Status Pekerjaan}

Mahasiswa UT tidak bersifat homogen, dalam pengertian tidak semua berstatus fresh graduate sehingga perlu untuk diketahui apakah responden menunjukkan fenomena yang berbeda. Untuk yang berusaha sendiri sebanyak 27 orang, yang berstatus pekerja atau karyawan sebanyak 83 orang, karyawan tidak tetap sebanyak 34 orang dan yang tidak bekerja saat ini sebanyak 6 orang. Tingkat persentase dapat dilihat pada Tabel 3 .

Tabel 3. Status Pekerjaan Mahasiswa NonPendas UPBJJ-UT Padang

\begin{tabular}{clc}
\hline No & Kategori & Persentase \\
\hline 1. & Usaha Sendiri/Wiraswasta & 9 \\
2. & Karyawan Tetap & 27.7 \\
3. & Karywan Tidak Tetap & 11.3 \\
4. & Tidak Bekerja & 2 \\
\hline
\end{tabular}

\section{Latar Belakang Pendidikan}

Untuk latar belakang pendidikan dari kuesioner yang disebarkan, data SMA sederajat sebanyak 101 orang mahasiswa dan Diploma sebanyak 49 orang responden. Tingkat persentase dapat dilihat pada Tabel 4 .

Tabel 4. Latar Belakang Pendidikan Mahasiswa Non-Pendas UPBJJ-UT

\begin{tabular}{clc}
\hline No. & Kategori & Persentase \\
\hline 1 & SMA Sederajat & 33.7 \\
2 & Diploma & 16.3 \\
\hline
\end{tabular}

\section{Tujuan Masuk UT}

Pertanyaan berikutnya untuk mengetahui sejauh mana tujuan mahasiswa masuk atau menjadi mahasiswa UT, dari 150 kuesioner yang kembali didapat data sebagai berikut. Tujuan masuk UT untuk memperoleh gelar 77 orang dan promosi jabatan 33 orang. Untuk masing pertanyaan mengenai tujuan masuk UT mengisi waktu dan menambah ilmu adalah sebanyak 20 orang. Tingkat persentase dapat dilihat pada Tabel 5 .

\section{Tabel 5. Tujuan Masuk UT}

\begin{tabular}{clc}
\hline No. & Kategori & Persentase \\
\hline 1. & Memperoleh Gelar & 25.7 \\
2. & Promosi Jabatan & 11.0 \\
3. & Mengisi waktu luang & 6.7 \\
4. & Menambah Ilmu & 6.7 \\
\hline
\end{tabular}

\section{Motivasi Kuliah di UT}

Setiap Individu mempunyai daya atau motivasi tersendiri, sehingga dapat dipastikan ada perbedaan motivasi. Dari 150 kuesioner yang kembali maka didapat data. Untuk mahasiswa yang ingin cepat lulus sebanyak 70 orang, untuk konsentrasi nilai bagus sebanyak 67 orang dan untuk yang ingin menguasi ilmu hanya 13 orang. Tingkat persentase dapat dilihat pada Tabel 6.

\begin{tabular}{|c|c|c|}
\hline No. & Kategori & Persentase \\
\hline 1. & Cepat Lulus & 23.3 \\
\hline 2. & Nilai Bagus & 22.3 \\
\hline 3. & Menguasi Bidang & 4.3 \\
\hline
\end{tabular}


Faktor eksternal mengenai pengetahuan mahasiswa tentang layanan belajar, akses layanan belajar, tutorial online, kualitas buku dari segi tampilan dan isi, kemudahan dalam mengakses toko buku online dan layanan belajar lain.

\section{Mengetahui Layanan Belajar di UT}

Pertanyaan dari faktor eksternal yang pertama adalah mengetahui layanan belajar di UT. Responden menjawab tahu sebanyak 145 orang dan yang tidak tahu hanya 5 orang. Tingkat persentase dapat dilihat pada Tabel 7.

Tabel 7. Layanan Belajar di UT

\begin{tabular}{clc}
\hline No. & Kategori & Persentase \\
\hline 1. & Tahu & 96.7 \\
2. & Tidak Tahu & 3.3 \\
\hline
\end{tabular}

\section{Mengkases Layanan Belajar}

Untuk mengetahui apakah mahasiswa pernah mengakses layanan belajar, maka didapat data untuk yang mengakses tutorial online sebanyak 92 orang, Toko Buku Online (TBO) sebanyak 31 orang, perpustakaan digital 7 orang dan yang mengakses layanan belajar lainnya sebanyak 7 orang. Tingkat persentase dapat dilihat pada Tabel 8.

Tabel 8. Akses Layanan Belajar

\begin{tabular}{clc}
\hline No. & Kategori & Persentase \\
\hline 1. & Tutorial Online & 61.3 \\
2. & Toko Buku Online & 20.7 \\
3. & Perpustakaan Digital & 8.7 \\
4. & ITV & 4.7 \\
6 & Lain-lain & 4.7 \\
\hline
\end{tabular}

\section{Mengikuti Tutorial Online}

Pada faktor ekternal untuk mengetahui apakah mahasiswa mengikuti tutorial online atau tidak, dari kuesioner yang disebar terdapat data, untuk yang mengikuti tutorial online didapat jumlah mahasiswa yang mengikuti dari 150 kuesioner yaitu sebanyak 119 orang mahasiswa dan 31 orang tidak pernah mengikuti tutorial online. Tingkat persentase dapat dilihat pada Tabel 9.
Tabel 9. Mengikuti Tutorial Online

\begin{tabular}{lll}
\hline No. & Kategori & Persentase \\
\hline 1. & Ada & 79.3 \\
2. & Tidak Ada & 20.7 \\
\hline
\end{tabular}

\section{Membeli Buku}

Pertanyaan lain tentang apakah anda pernah membeli buku. Dari responden yang memberikan jawaban, sebanyak 31 orang menyatakan pernah membeli dan sebanyak 150 orang tidak pernah membeli buku. Tingkat persentase dapat dilihat pada Tabel 10.

\section{Tabel 10. Membeli Buku melalui TBO}

\begin{tabular}{lll}
\hline No. & Kategori & Persentase \\
\hline 1. & Pernah & 20.7 \\
2. & Tidak Pernah & 79.3 \\
\hline
\end{tabular}

\section{Kualitas Tampilan Buku UT}

Pertanyaan selanjutnya mengenai buku adalah mengenai kualitas tampilan buku. Untuk pertanyaan kulit mudah lepas ternyata tidak ada satupun responden yang memberi respon dengan kata lain nihil, sedang yang menjawab bagus sebanyak 31 orang. Dengan demikian, responden yang tidak memberikan jawaban untuk pertanyaan ini sebanyak 119 orang responden dari 150 kuesioner. Tingkat persentase dapat dilihat pada Tabel 11.

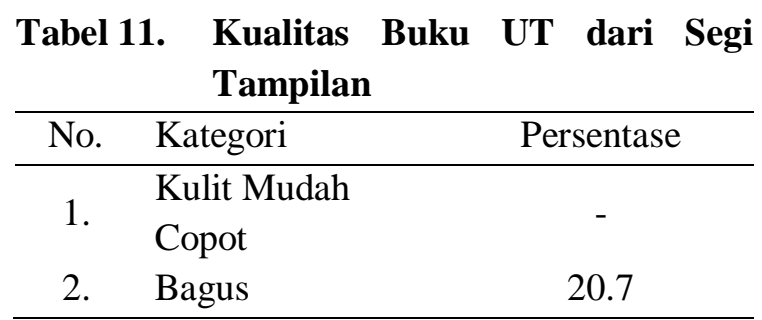

\section{Kualitas Isi Buku}

Pertanyaan berikut mengenai tentang kualitas isi buku, 150 responden terdata 10 orang yang menyatakan mudah dipahami, 71 orang menyatakan tidak tahu dan 69 orang menyatakan sulit untuk dipelajari sendiri. Tingkat persentase dapat dilihat pada Tabel 12. 
Tabel 12. Kualitas Isi Buku

\begin{tabular}{lll}
\hline No. & Kategori & Persentase \\
\hline 1. & Mudah dipahami & 6.7 \\
2. & Sulit & 47.3 \\
3. & Tidak mudah untuk & 46.0 \\
& dipelajari sendiri & \\
\hline
\end{tabular}

\section{Kemudahan dalam Mengakses Toko Buku Online (TBO)}

Pertanyaan berikut tentang kemudahan dalam mengakses toko buku online yang disediakan oleh Universitas Terbuka melalui website, ada sebanyak 46 orang yang menyatakan bahwa prosedurnya sulit, akses internet mudah ada sebanyak 68 responden yang menjawab. Untuk yang menjawab mudah dari 150 kuesioner hanya 31 orang yang menyatakan mudah dan 5 orang menyatakan tidak tahu. Tingkat persentase dapat dilihat pada Tabel 13.

\section{Tabel 13. Akses Toko Buku Online}

\begin{tabular}{lll}
\hline No. & Kategori & Persentase \\
\hline 1. & Sulit Prosedur & 30.7 \\
2. & Akses Internet & 45.3 \\
& Mudah & \\
3. & Mudah & 20.7 \\
4. & Tidak Tahu & 3.3 \\
\hline
\end{tabular}

\section{Kemudahan Mengkases Layanan Belajar Lain}

Pertanyaan terakhir yang dari faktor eksternal adalah mengenai kemudahan dalam mengakses layanan belajar lain. Sebanyak 68 orang yang menjawab akses internet susah, 7 orang menjawab mudah dan 65 orang yang menyatakan tidak tahu. ingkat persentase dapat dilihat pada Tabel 14.

Tabel 14. Akses Layanan Belajar Lain

\begin{tabular}{lll}
\hline No. & Kategori & Persentase \\
\hline 1. & Akses Internet & 45.3 \\
& Susah & \\
2. & Mudah & 4.7 \\
3. & Tidak Tahu & 43.3
\end{tabular}

Mahasiswa UT diharapkan dapat belajar secara mandiri. Diklat jarak jauh adalah model pembelajaran yang membebaskan peserta untuk belajar tanpa terikat oleh ruang dan waktu dengan sesedikit mungkin bantuan dari orang lain (Warsita, 2011). Suherman (2004) menyatakan bahwa setiap mahasiswa adalah individu yang memiliki potensi untuk belajar mandiri, baik dari sumber tertulis, media massa atau lingkungannya. Cara belajar mandiri menghendaki mahasiswa untuk belajar atas prakarsa atau inisiatif sendiri. Belajar mandiri dapat dilakukan secara sendiri ataupun berkelompok, baik dalam kelompok belajar maupun dalam kelompok tutorial. UT menyediakan bahan ajar yang dibuat khusus untuk dapat dipelajari secara mandiri. Selain menggunakan bahan ajar dapat juga memanfaatkan fasilitas yang disediakan di website UT, maupun melalui radio dan televisi (Tim Universitas Terbuka, 2012).

Hasil belajar atau kompetensi didefinisikan oleh Ibrahim (2005) sebagai produk, keterampilan, dan sikap yang tercermin di dalam perilaku sehari-hari. Faktor-faktor yang mempengaruhi prestasi belajar siswa distance education menurut Keegan (1996) adalah institution, student characteristics, learning materials, student support services, and medium. Tait (1992) secara umum menjelaskan bahwa yang mempengaruhi prestasi belajar siswa open learning adalah policy and management, student support development, technology, learning materials, and student.

Aktivitas belajar para mahasiswa NonPendas UPBJJ-UT Padang berpengaruh secara signifikan terhadap prestasi belajar mereka. Berdasarkan analisis nilai kualitas model regresi linier berganda yang terbentuk yaitu $\ddot{Y}=1,861-0,111 X_{1}-0,172 X_{2}-0,243 X_{3}+0,597 X_{4}$ maka nilai koefisien determinasi ( $\mathrm{R}$ square) sebesar 59,8\%. Nilai tersebut menunjukkan informasi bahwa 59,8\% nilai prestasi belajar telah dapat dijelaskan oleh data akses layanan belajar, mengikuti tutorial online, membeli buku di TBO, dan akses TBO. Sedangkan sisanya $40,2 \%$ informasi mengenai prestasi belajar belum dapat dijelaskan oleh variabelvariabel bebas tersebut. Untuk melihat ada atau tidaknya multikolinearitas yang terjadi antar variabel bebas pembentuk model persamaan regresi linier berganda. Hasil analisis tersebut diketahui bahwa antar variabel bebas (akses 
layanan belajar, mengikuti tutorial online, membeli buku di TBO, dan akses TBO) tidak terjadi multikolinearitas. Hal ini dapat dilihat dari nilai korelasi antar variabel bebas jauh dibawah patokan yang biasa digunakan yaitu 0,8 (Umar, 2009).

\section{PENUTUP}

Aktivitas belajar mahasiswa Non-Pendas di UPBJJ Padang masih rendah karena motivasinya hanya mengejar ijazah. Faktor-faktor yang memengaruhi aktivitas belajar adalah ikut tutorial online, akses layanan belajar, serta membeli buku di toko buku online. Layanan belajar dan bahan ajar berpengaruh signifikan terhadap prestasi belajar. Implikasi penelitian ini adalah aktivitas belajar mahasiswa UT khususnya Non-Pendas dapat ditingkatkan dengan sosialisasi berkesinambungan dalam hal akses terhadap layanan belajar dan bahan ajar. Diharapkan pihak manajemen dapat menjalin kerjasama terkait kesulitan mahasiswa dalam mengakses internet.

\section{UCAPAN TERIMA KASIH}

Terima kasih penulis ucapkan kepada semua pihak yang telah membantu sehingga hasil penelitian dalam bentuk artikel ini dapat diselesaikan. Terimakasih kepada LPPM UT yang telah memberikan bantuan telaah materi dan materil, Kepala UPBJJ-UT Padang untuk izin penelitian yang diberikan, serta semua responden yaitu mahasiswa Non-Pendas UPBJJUT Padang atas bantuan dalam pelaksanaan penelitian.

\section{DAFTAR PUSTAKA}

Erita, S. 2009. Pengaruh Strategi Belajar Aktif Tipe Kuis Tim Terhadap Hasil Belajar Matematika di SMP Negeri 25 Padang. UNP: Tesis tidak dipublikasikan.

Ibrahim, M. 2005. Asesmen Berkelanjutan: Konsep Dasar, Tahapan Pengembangan dan Contoh. Surabaya:Unesa UinversityPress.
Idiarman. 2009. Peningkatan Aktivitas dan Hasil Belajar Matematika Siswa Melalui Model Pembelajaran Kooperatif Tipe STAD. UNP: Tesis tidak dipublikasikan.

Keegan, D. 1996. Foundation of Distance Education. Third edition, London, Routledge.

Sardiman, A.M. 2006. Interaksi \& Motivasi Belajar Mengajar. Jakarta: PT. Raja Grafindo Persada.

Sugiyono. 2007. Metode Penelitian Pendidikan: Pendekatan Kuantitatif, Kualitatif, $d a R \& D$. Bandung: Alfabeta.

Suherman, E. 2004. Common Textbook Strategi Pembelajaran Matematika Kontemporer. Bandung: JICA-Universitas Pendidikan Indonesia (UPI).

Tait, A. 1992. Key Issues in Open Learning. London: Longman information and Reference ltd.

Tim Universitas Terbuka. 2012. Katalog Universitas Terbuka 2012. Jakarta: Universitas Terbuka.

Umar, H. 2009. Metode Penelitian Untuk Skripsi dan Tesis Bisnis. Edisi Kedua. Jakarta: Rajawali Pers.

Warsita, B. 2011. Pendidikan Jarak Jauh: Perancangan, Pengembangan, Implementasi, dan Evaluasi Diklat. Bandung: PT Remaja Rosdakarya.

Zaini, H. 2002. Desain Pembelajaran di Perguruan Tinggi. Yogyakarta: Center For Teching Staff Development (CTSD) IAIN Sunan Kalijaga. 